\title{
Effects of phosphorus loading on interactions of algae and bacteria: reinvestigation of the 'phytoplankton-bacteria paradox' in a continuous cultivation system
}

\author{
Birgit Mindl ${ }^{1}$, Bettina Sonntag ${ }^{1}$, Jakob Pernthaler ${ }^{2}$, Jaroslav Vrba ${ }^{3}$, Roland Psenner ${ }^{1}$, \\ Thomas Posch ${ }^{1, *}$ \\ ${ }^{1}$ Institute of Zoology and Limnology, University of Innsbruck, Technikerstraße 25, 6020 Innsbruck, Austria \\ ${ }^{2}$ Max Planck Institute for Marine Microbiology, Celsiusstraße 1, 28359 Bremen, Germany \\ ${ }^{3}$ Hydrobiological Institute AS CR, Na sádkách 7, 37005 České Budějovice, Czech Republic
}

\begin{abstract}
The effect of different phosphorus loads $\left(\mathrm{L}_{\mathrm{P}}\right)$ on the phosphorus $(\mathrm{P})$ and carbon $(\mathrm{C})$ content (biomass) of algae and bacteria was assessed in continuous culture. We tested if a mixed freshwater microbial assemblage co-cultured with a phytoflagellate (Cryptomonas phaseolus) would comply with the 'phytoplankton-bacteria paradox' (sensu Bratbak \& Thingstad 1985). This hypothesis states that the ratio of bacterial to algal abundance changes to the benefit of bacteria with decreasing $\mathrm{L}_{\mathrm{p}}$. However, the phenomenon was originally investigated by simultaneously altering $\mathrm{L}_{\mathrm{P}}$ and microbial growth rates, and it is unclear to which extent it can be assigned to either parameter. Therefore, we set up 3 chemostat systems in triplicate at equal dilution rates, but with daily $L_{p}$ of 21,41 or $62 \mu \mathrm{g}$ $\mathrm{l}^{-1} \mathrm{~d}^{-1}$ (corresponding to 50, 100 and $150 \mu \mathrm{g} \mathrm{P}^{-1}$ ). Higher $\mathrm{L}_{\mathrm{P}}$ led to a 5-fold increase in total algal abundance and biomass but to less than a doubling of these parameters in the bacterial assemblage. Total biomass ratios of bacteria to algae changed from 0.18 to 0.06 with increasing $L_{P}$, while the bacteria-algae total phosphorus ratios decreased from 0.80 to 0.17 . The cellular C:P ratio of algae remained similar at all $\mathrm{P}$ concentrations, whereas the molar C:P ratios of bacterial cells significantly increased at higher $\mathrm{L}_{\mathrm{P}}$ (from 44 to 73 ). An enrichment experiment with the $50 \mu \mathrm{g} \mathrm{P} \mathrm{l}^{-1}$ treatment demonstrated that bacteria at the lowest $\mathrm{L}_{\mathrm{p}}$ were co-limited by $\mathrm{P}$ and $\mathrm{C}$, and that increased $\mathrm{P}$ stimulated mainly the algal fraction. The phytoplankton-bacteria paradox at the level of a mixed microbial assemblage is thus characterised by the following aspects: (1) bacteria profit from their high affinity to $\mathrm{P}$ and are better competitors at lower $\mathrm{L}_{\mathrm{P} i}(2)$ although algae compete with bacteria for $\mathrm{P}, \mathrm{P}$-limited algae release extracellular $C$ that stimulates growth of their bacterial competitors; (3) when bacteria depend on algae as their sole source of organic $C$, this provides a feedback mechanism by which algae limit the abundance of their competitors at higher $\mathrm{L}_{\mathrm{p}}$ (4) large oscillations in the bacteria-algae ratios at the lowest $\mathrm{L}_{\mathrm{P}}$ point to a greater instability of this interaction with stronger $\mathrm{P}$ competition. However, bacteria were not able to outcompete C. phaseolus, as algae were their only C source.
\end{abstract}

KEY WORDS: Algae-bacteria interaction $\cdot$ Chemostat $\cdot$ Continuous cultivation system $\cdot$ Cryptomonas phaseolus $\cdot$ Eutrophication · Phosphorus $\cdot$ Phytoplankton-bacteria paradox

\section{INTRODUCTION}

Traditionally, pelagic heterotrophic bacteria have almost exclusively been regarded as 'mineralisers' of nutrients bound in detrital organic matter, thus supporting algal production with recycled dissolved phos- phorus and other inorganic nutrients. However, planktonic algae and bacteria exhibit more complex ecological interactions that cannot easily be described by simple mineralization-based models (Fogg 1971, Currie 1990, Grossart 1999, Gurung et al. 1999). If bacterial production is limited by the supply of key 
nutrients, such as nitrogen or phosphorus, the relationship between bacteria and algae is not considered mutualistic, but competitive (Currie \& Kalff 1984b, Elser et al. 1995, Vadstein 2000).

The competition for $\mathrm{P}$ between bacteria and algae cannot easily be studied in situ, i.e. in a planktonic food web of high complexity. Continuous cultivation systems have the advantage that algae and bacteria experience fewer environmental fluctuations and can be cultivated at known specific growth rates. In addition, the systems can easily be replicated. Seminal chemostat experiments by Bratbak \& Thingstad (1985) showed that a marine bacterial isolate acquired P more efficiently than a diatom when the phosphorus loads $\left(L_{P}\right)$ was decreased by reduction of the dilution rate. Since extracellular organic carbon (EOC) release by algae was the only carbon source for the bacteria, a paradoxical situation developed: although bacteria became more competitive in sequestering $\mathrm{P}$ at low $\mathrm{P}$ concentrations (or lower growth rate), algae still supported bacterial carbon demand by EOC release. Thus, the algae supported the growth of their own competitors, and the bacterial versus algal $\mathrm{P}$ ratio increased with stronger $\mathrm{P}$ limitation. The authors termed their observations the 'phytoplankton-bacteria paradox'. However, since the P limitation in the chemostat system was induced indirectly by a change of the dilution rate, the possibility cannot be excluded that this phenomenon was related to physiological adaptations of the algae or bacteria to decreased growth rates.

Rapidly growing bacterial cells are characterised by lower C:P ratios than slowly growing cells (Chrzanowski et al. 1996, Makino et al. 2003). The C:P of algae may decrease from $\sim 1000$ to 100 with increasing growth rates (Gächter \& Bloesch 1985). Both bacteria and algae have the ability to store $\mathrm{P}$ and $\mathrm{N}$ surplus in excess of their actual demand, which is reflected by the high variability of the intracellular nutrient content in natural populations (Vrede et al. 2002). Thus, the nutrient flux within the microbial food web and the competition for nutrients are also influenced by growth rate-related stoichiometric constraints.

To assess the effect of different $L_{P}$ on bacteria-algae interactions, we performed an experiment with the phytoflagellate Cryptomonas phaseolus and a mixed bacterial assemblage in continuous culture. The following questions and hypotheses were addressed: (1) Is the phytoplankton-bacteria paradox (Bratbak \& Thingstad 1985) confirmed for a mixed bacterial assemblage if the dilution rate (growth rate) is kept constant, and only the P loadings are varied? (2) If so, to which extent is this paradoxical situation reflected in different community parameters, specifically in the abundance, biomass (i.e. total organic $\mathrm{C}$ ) and $\mathrm{P}$ content of the algal and bacterial assemblage? (3) Which single-cell characteristics of bacteria and algae (elemental content, stoichiometry, cell dimensions) change with different $\mathrm{P}$ loads? (4) Are bacteria increasingly C-limited at lower $\mathrm{P}$ concentrations, in parallel with increasing bacterial to algal biomass ratio?

\section{MATERIALS AND METHODS}

Experimental design. Experiments were performed in 9 chemostat vessels (see Posch et al. 1999 for a schematic drawing) with a dilution rate of $0.41 \mathrm{~d}^{-1}$, corresponding to approximately 20 analysed generations of bacteria and algae over the investigation period (37 d). The phytoflagellate Cryptomonas phaseolus was grown on an inorganic medium (Guillard \& Lorenzen 1972) in these continuous-flow systems together with an accompanying mixed bacterial assemblage (Pernthaler et al. 2001) fuelled by organic substrates released by the algae. C. phaseolus seems to be a true photoautotrophic organism, as we never observed any uptake of bacteria by the phytoflagellate in former experiments (Šimek et al. 1997, Posch et al. 2001). Phosphorus concentrations were adjusted with $\mathrm{K}_{2} \mathrm{HPO}_{4}$ to obtain P levels of $50 \mu \mathrm{g} \mathrm{P} \mathrm{l^{-1 }}$ (P50), $100 \mu \mathrm{g} \mathrm{P} \mathrm{l}^{-1}$ (P100) and $150 \mathrm{\mu g} \mathrm{P} \mathrm{l}^{-1}$ (P150) in triplicate flow-systems under controlled laboratory conditions. The daily phosphorus loads $\left(\mathrm{L}_{\mathrm{P}}\right)$ were $21 \mu \mathrm{g} \mathrm{P} \mathrm{l}^{-1} \mathrm{~d}^{-1}\left(0.6 \mu \mathrm{M} \mathrm{d}^{-1}\right)$ in P50, $41 \mu \mathrm{g} \mathrm{P} \mathrm{l}^{-1} \mathrm{~d}^{-1}\left(1.3 \mu \mathrm{M} \mathrm{d}^{-1}\right)$ in P100, and $62 \mu \mathrm{g}$ $\mathrm{P}^{-1} \mathrm{~d}^{-1}\left(1.9 \mu \mathrm{M} \mathrm{d}^{-1}\right)$ in P150. Nitrogen was supplied as $\mathrm{NO}_{3}{ }^{-}$at non-limiting concentrations and the $\mathrm{N}: \mathrm{P}$ weight ratios were 280:1, 140:1, and 93:1 for P50, P100, and P150, respectively.

We used 3 glass bottles of $10 \mathrm{l}$ each to store the inorganic media, and these had to be refilled every $8 \mathrm{~d}$. The culture vessels with a volume capacity of $780 \mathrm{ml}$ were aerated from the bottom and had a lateral outflow. Silicon tubes with an inner diameter of 2 to $5 \mathrm{~mm}$ were utilised for the connections. A peristaltic pump (Digital Drive MCP with cartridge pump heads; Ismatec) and pumping tubes with inner diameters of $2.06 \mathrm{~mm}$ (Ismatec) were used for the transport of the media. All parts were rinsed with distilled water and sterilised before the system was assembled in a walkin chamber at $16^{\circ} \mathrm{C}$. All cultures were kept under constant light intensity $\left(\sim 120 \mu \mathrm{E} \mathrm{m} \mathrm{m}^{-2} \mathrm{~s}^{-1}\right)$ with a $16: 8 \mathrm{~h}$ light:dark cycle. The vessels were filled with media and inoculated with $20 \mathrm{ml}$ each of a pure stock culture of Cryptomonas phaseolus and its accompanying bacteria. Pumping was stopped for $4 \mathrm{~d}$ to establish the experimental communities. Subsequently, the dilution rate was set at $0.41 \mathrm{~d}^{-1}$ and the first samples were taken (Day 0 of the experiment).

Sampling and sample preparation. Subsamples of $120 \mathrm{ml}$ were collected from each vessel into sterile 
$250 \mathrm{ml}$ Schott-bottles every second day until Day 10 . Afterwards, samples were taken at 5 to $9 \mathrm{~d}$ intervals. Occasionally, the inner walls of the vessels were scrubbed manually with a bar magnet to reduce algal and bacterial wall-growth. All subsamples for counting and sizing of bacteria and algae were prefixed with alkaline Lugol's solution ( $0.5 \%$ final conc.) immediately followed by formaldehyde ( $2 \%$ final conc.) fixation, and bleached with some drops of sodium thiosulphate ( $3 \%$ stock solution).

Heterotrophic bacteria and algae. Bacterial and algal cells were counted after DAPI staining with a Zeiss Axioplan or a Zeiss Axiophot 2 (for algal counts) epifluorescence microscope following the protocol of Porter \& Feig (1980). For a more detailed description of the methods see Šimek et al. (1997) and Posch et al. (2001). Mean cell volumes of organisms were determined by image-analysis (Lucia D, Laboratory Imaging: see www.lim.cz). At least 300 algae and 500 bacteria per sample were measured. Bacterial cell carbon content and total bacterial biomass were calculated according to Loferer-Krößbacher et al. (1998): $\mathrm{CC}=218 \cdot \mathrm{V}^{0.86}, \mathrm{BM}=\mathrm{CC} \cdot \mathrm{N}$, where $\mathrm{CC}$ is bacterial cell carbon (fg $\mathrm{C}$ cell-1 ${ }^{-1}$ ), $\mathrm{V}$ is bacterial cell volume

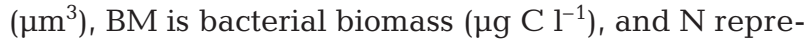
sents bacterial abundance (cells $\mathrm{l}^{-1}$ ). The carbon content of Cryptomonas phaseolus cells was estimated using the conversion factor of Menden-Deuer \& Lessard (2000): $\mathrm{CC}=216 \cdot \mathrm{V}^{0.939}$. It was verified during a separate pilot study by direct measurements of algal carbon content in treatments enriched with 50

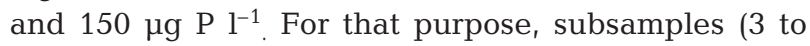
$5 \mathrm{ml}$ ) of the algal cultures were filtered at low vacuum (100 $\mathrm{mm} \mathrm{Hg}$ ) onto pre-combusted glass-fibre filters GF8 (13 mm in diameter, Schleicher and Schüll) which were frozen $\left(-20^{\circ} \mathrm{C}\right)$ until analysis (Bertoni 1978). The organic elemental analyses were done by the company ThermoFinnigan with a Flash EA 1112 NC analyzer, and atropine (1 to $1.5 \mathrm{mg}$ ) was used as a standard. No correction for bacterial contamination was applied, because only $<15 \%$ of the bacteria were retained by the GF8 filters used for the concentration of algae.

Phosphorus content of bacteria and algae. In order to separately measure the $\mathrm{P}$ content of algae and bacteria, subsamples $(25 \mathrm{ml})$ were filtered at low vacuum (100 $\mathrm{mm} \mathrm{Hg}$ ) onto white $3 \mu \mathrm{m}$ pore-sized polycarbonate membrane filters ( $47 \mathrm{~mm}$ in diameter; Millipore). For measurements of total dissolved phosphorus (TDP), we filtered subsamples $(25 \mathrm{ml})$ through $0.2 \mu \mathrm{m}$ polycarbonate membrane filters. Phosphorus concentrations of the whole sample (TP) and of the different size fractions, i.e. $>3 \mu \mathrm{m}$ (algae), $>0.2$ and $<3 \mu \mathrm{m}$ (bacteria), and $<0.2 \mu \mathrm{m}$ (TDP) were determined by spectrophotometry using the molybdate method after digestion with $\mathrm{H}_{2} \mathrm{SO}_{4}$ and $\mathrm{H}_{2} \mathrm{O}_{2}$ (Schmid \& Ambühl
1965). The percentage of bacteria retained on the $3 \mu \mathrm{m}$ filters was checked by epifluorescence microscopy (up to $15 \%$ of total bacterial number were retained). The number of retained bacteria was multiplied by the mean bacterial $\mathrm{P}$ content and this value was used to correct the determinations of total algal and bacterial $\mathrm{P}$ content (resulting in a 5 to $15 \%$ correction of measured values).

Nutrient enrichment experiment. We took a $120 \mathrm{ml}$ subsample of the P50 chemostat vessels and prepared 4 treatments $(30 \mathrm{ml}$ each) that were kept as batchcultures for 1 wk: 1 treatment served as a control, whereas the other 3 were enriched with carbon $(+C)$, phosphorus (+P) or carbon plus phosphorus (+CP). Surplus phosphorus was added as $\mathrm{K}_{2} \mathrm{HPO}_{4}$ to give a final concentration of $150 \mu \mathrm{g} \mathrm{P} \mathrm{l}{ }^{-1}$, corresponding to the P150 chemostat vessels. Carbon was added as glucose to a molar C:P ratio of 100:1, resulting in a final concentration of $14.5 \mathrm{mg}$ glucose $\mathrm{l}^{-1}$. Abundance and biomass of organisms were determined daily during $1 \mathrm{wk}$.

Statistical analyses. We used a 2-way ANOVA (factors: P concentration and time) for repeated measurements, with post-hoc comparisons using Bonferroni-corrected $t$-tests. All statistical analyses were performed using SigmaStat (Version 2.03, SPSS). To control the overall experimental Type I error, we corrected the significance level according to the Bonferroni method as $\{\alpha /[n(n-1) / 2]\}$, where $\alpha$ is the probability level and $\mathrm{n}$ is the number of observations.

\section{RESULTS}

The continuous cultivation systems were sampled 10 times within $37 \mathrm{~d}$. Since P concentrations were regulated via the concentration of the media and not by changed dilution rates, growth rates were fairly constant over the investigation period (Table 1). Total dissolved phosphorus was generally below the detection limit $\left(<1 \mu \mathrm{g} \mathrm{P} \mathrm{l}^{-1}\right.$; data not shown), i.e. all $\mathrm{P}$ was incorporated by the algae and bacteria.

\section{Abundance and biomass}

EOC released by algae growing on the mineral medium was the sole substrate source for the accompanying bacterial assemblage. Neither trace amounts of vitamins nor an organic buffer (115 $\mathrm{mg} \mathrm{l}^{-1}$ of TES buffer, Sigma) allowed bacterial growth in batch experiments. We observed 2 phases of population development. After inoculation of the stock culture the system was rather instable between Days 0 and 10. After Day 10 (approximately 5 generations), however, all cultures reached a steady state. Average values of bac- 
Table 1. Algae Cryptomonas phaseolus and their associated mixed bacterial assemblage. Abundance, biomass, total phosphorus

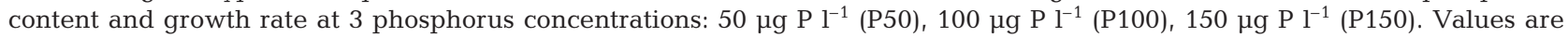
means $(n=10)$ of 3 parallel systems over whole investigation period of $37 \mathrm{~d}$. Minimum and maximum data given in parentheses. B: bacteria; A: algae. Values of P100 and P150 were compared with values of P50 to quantify increase in bacterial and algal parameters

\begin{tabular}{|c|c|c|c|c|c|c|}
\hline Parameter & \multicolumn{2}{|c|}{ P50 } & \multicolumn{2}{|c|}{ P100 } & \multicolumn{2}{|c|}{ P150 } \\
\hline Bacteria $\left(10^{6}\right.$ cells $\left.\mathrm{ml}^{-1}\right)$ & 6.84 & (4.27-9.94) & 10.30 & $(7.23-14.44)$ & 1320 & $(8.23-18.12)$ \\
\hline Algae $\left(10^{4}\right.$ cells ml $\left.l^{-1}\right)$ & $\begin{array}{l}0.04 \\
2.36\end{array}$ & $(1.39-3.58)$ & 7.96 & $(7.14-8.62)$ & 11.75 & $(10.51-13.99)$ \\
\hline $\mathrm{B}: \mathrm{A}$ ratio & 290 & & 129 & & 112 & \\
\hline B increase vs. P50 & - & & 1.5 & & 1.9 & \\
\hline A increase vs. P50 & - & & 3.4 & & 5.0 & \\
\hline \multicolumn{7}{|l|}{ Biomass } \\
\hline Bacteria $\left(\mu g \mathrm{C}^{-1}\right)$ & 258 & $(180-451)$ & 391 & $(266-643)$ & 480 & $(339-738)$ \\
\hline Algae $\left(\mu g \mathrm{C}^{-1}\right)$ & 1471 & (839-2229) & 4544 & $(3262-5972)$ & 7407 & $(5468-8871)$ \\
\hline $\mathrm{B}: \mathrm{A}$ ratio & 0.18 & & 0.09 & & 0.06 & \\
\hline $\mathrm{B}$ increase vs. P50 & - & & 1.5 & & 1.9 & \\
\hline A increase vs. P50 & - & & 3.1 & & 5.0 & \\
\hline \multicolumn{7}{|l|}{ Phosphorus content } \\
\hline Bacteria $\left(\mu \mathrm{g} \mathrm{P} \mathrm{l^{-1 } )}\right.$ & 16.5 & $(12.0-22.7)$ & 16.9 & $(12.3-22.9)$ & 18.4 & $(12.5-23.7)$ \\
\hline Algae $\left(\mu g \mathrm{P}^{-1}\right)$ & 19.5 & $(10.5-27.8)$ & 63.7 & $(55.7-70.1)$ & 108.0 & $(91.4-123.4)$ \\
\hline B:A ratio & 0.80 & & 0.31 & & 0.17 & \\
\hline B increase vs. P50 & - & & 1.0 & & 1.1 & \\
\hline A increase vs. P50 & - & & 3.3 & & 5.6 & \\
\hline \multicolumn{7}{|l|}{ Growth rate } \\
\hline Bacteria $\left(\mathrm{d}^{-1}\right)$ & 0.46 & $(0.38-0.49)$ & 0.43 & $(0.34-0.46)$ & 0.43 & $(0.36-0.52)$ \\
\hline Algae $\left(\mathrm{d}^{-1}\right)$ & 0.39 & $(0.27-0.51)$ & 0.40 & $(0.27-0.46)$ & 0.40 & $(0.37-0.45)$ \\
\hline B:A ratio & 1.18 & & 1.08 & & 1.08 & \\
\hline
\end{tabular}

terial and algal abundance and biomass in the 3 different treatments are compiled in Table 1. In all set ups, bacterial cells increased during the first $10 \mathrm{~d}$ and stabilised thereafter. Algal cell numbers remained more or less stable throughout the experiment - with the exception of the P50 treatment, in which algal abundance decreased during the first $8 \mathrm{~d}$ from 3.5 to $1.8 \times$ $10^{4} \mathrm{cells} \mathrm{ml}^{-1}$. The increase in $\mathrm{P}$ concentrations of the medium from 50 to $150 \mathrm{\mu g} \mathrm{l}^{-1}$ caused a doubling of bacterial cell numbers, but a 5 -fold increase in algal abundance (Fig. 1, Table 1). Algal cell numbers significantly correlated with the $\mathrm{P}$ supply rates $\left(\mathrm{r}^{2}=0.93, \mathrm{n}=30, \mathrm{p}<\right.$ 0.001 ), while bacteria did not respond as strong on $P$ supply $\left(\mathrm{r}^{2}=0.42, \mathrm{n}=30, \mathrm{p}<0.05\right)$, i.e. bacterial growth did not keep pace with the increasing algal abundance. Algal and bacterial biomass showed the same trend as the corresponding abundance (Fig. 2), and biomass ratios of bacteria versus algae were 2 (P100) to 3 (P50) times higher than at P150, i.e. 0.18 (P50), 0.09 (P100), and $0.06(\mathrm{P} 150)(\mathrm{n}=30, \mathrm{p}<0.05$, Table 1).

\section{Algal and bacterial phosphorus}

The $L_{P}$ of the medium had a significant effect on the total P content of algae $(n=30, p<0.001)$, which increased more than 5-fold from P50 to P150. In contrast, the total P content of bacteria remained almost constant due to a drop in the per-cell P content (Fig. 3, Tables 1 \& 2). Thus, in P50, $46 \%$ of the TP was found in bacteria, whereas in P100 and P150 the bacterial contribution of TP decreased to 21 and $15 \%$, respectively. Therefore, the bacteria can be regarded as an important P-pool in

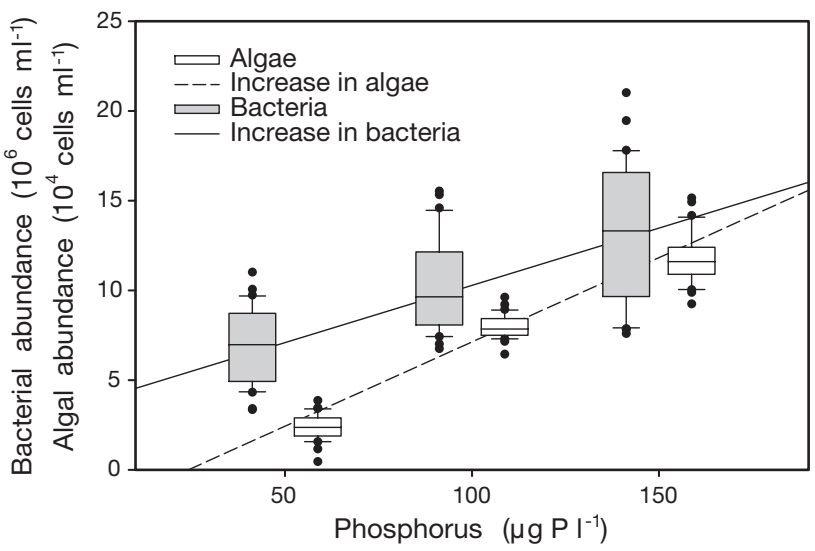

Fig. 1. Algae Cryptomonas phaseolus and mixed bacterial assemblage. Box-and-whisker plots of abundance over whole investigation period of $37 \mathrm{~d}$ at $3 \mathrm{P}$ concentrations $(50,100$, $150 \mu \mathrm{g} \mathrm{P} \mathrm{l}^{-1}$ ). Each box is based on $\mathrm{n}=30$ (3 triplicates sampled 10 times each). Bars show 25th, 50th and 75th percentiles of all data and whiskers 10th and 90th percentiles; data points are outliers. Trend lines show steep increase in algal and slower increase in bacterial abundance with increasing $\mathrm{P}$ load 


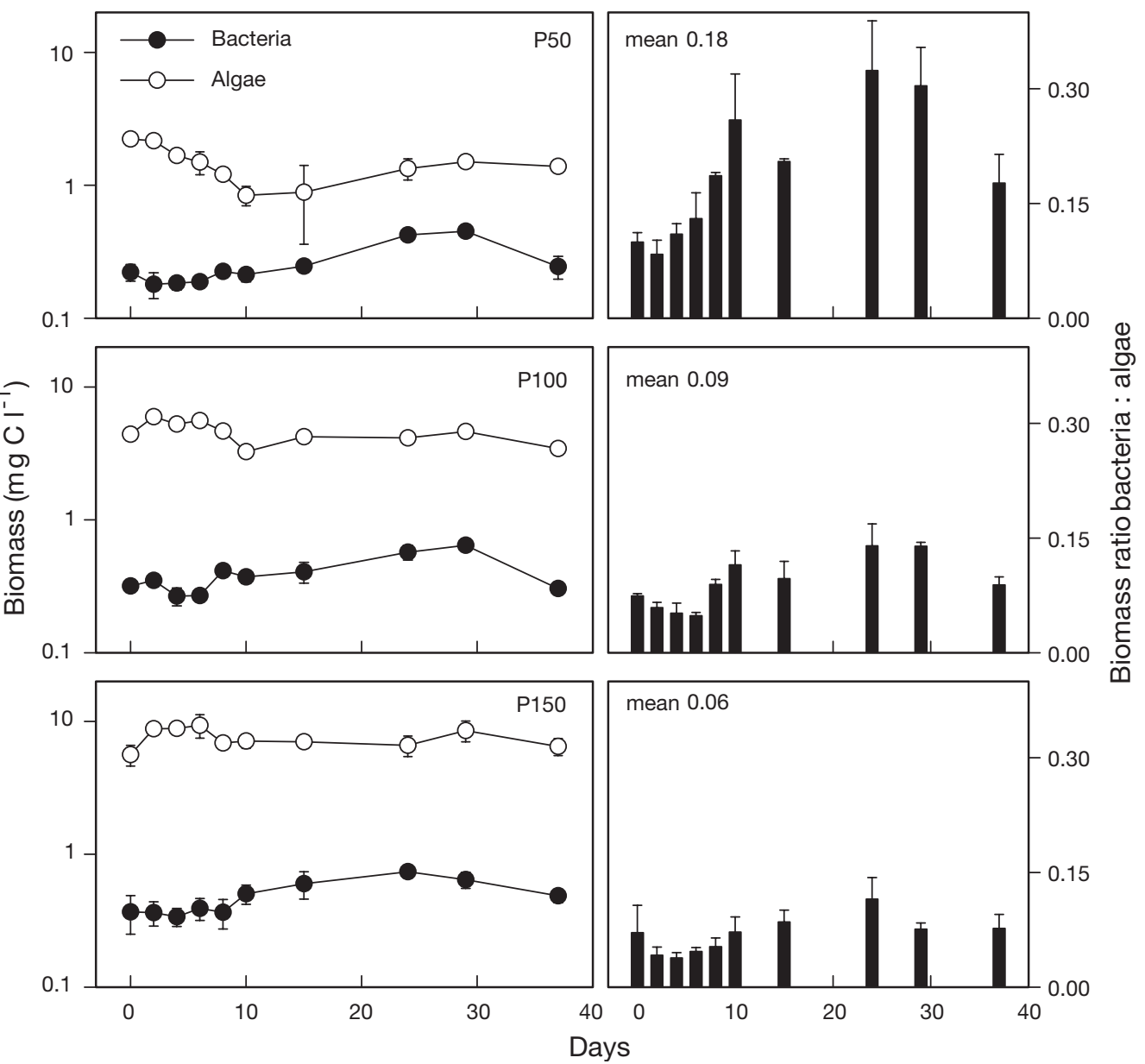

Fig. 2. Algae Cryptomonas phaseolus and mixed bacterial assemblage. Biomass over whole investigation period of $37 \mathrm{~d}$ at 3 $\mathrm{P}$ concentrations (P50, P100, P150: 50, 100, $150 \mu \mathrm{g} \mathrm{P} \mathrm{l}^{-1}$, respectively). Values are means ( $\pm 1 \mathrm{SD}$ ) of 3 parallel chemostats

the treatment with the lowest $\mathrm{P}$ supply, but their relative contribution to TP diminished at higher $\mathrm{L}_{\mathrm{P}}$.

\section{Cell-specific carbon and phosphorus content}

We found no distinct changes in the mean cell volume over the investigation period of either bacteria or algae (Table 2). The development of abundance and biomass showed similar trends. Phosphorus enrichment in the medium significantly affected the cellular $\mathrm{P}$ content of bacteria but not of algae. The mean P content of the bacterial cells was 2.4, 1.7, and $1.5 \mathrm{fg} \mathrm{P} \mathrm{cell}^{-1}$ in the P50, P100, and P150 treatments, respectively, and showed a significantly higher value in P50 than in the other treatments $(n=30, p<0.05$, Table 2$)$. Therefore, the C:P ratio of bacterial cells in P50 (C:P $=44)$ was significantly lower than in $\mathrm{P} 150(\mathrm{C}: \mathrm{P}=73 ; \mathrm{n}=30$, $\mathrm{p}<0.05)$. In contrast to bacteria, the $\mathrm{C}$ :P ratio of algae varied only within a narrow range (179 to 193), with slightly higher values in P50 $(\mathrm{n}=30$, not significant, Table 2). Microscopic observations of bacterial cells revealed the likely presence of polyphosphate granules in P50 during the first $20 \mathrm{~d}$, as indicated by very bright yellow grains inside the DAPI-stained cells.

\section{Nutrient enrichment experiment}

The transfer of organisms from the continuous cultivation to the batch-system caused a slight increase in bacterial abundance and biomass in the control (Fig. 4). Therefore, the bacterial to algal biomass ratio slowly increased until Day 6 (average $=0.23, \mathrm{n}=7$ ). The enrichment with glucose $(+C)$ caused mainly an increase in bacterial cell volume (data not shown) and total biomass, with no increase in abundance (Fig. 4). The bacterial to algal biomass ratio strongly increased (average $=0.45, \mathrm{n}=7$ ). Enrichment with phosphorus $(+\mathrm{P})$ stimulated both bacterial and algal growth, while bacterial 
Table 2. Algae Cryptomonas phaseolus and their associated mixed bacterial assemblage. Cell volume and cell-specific element

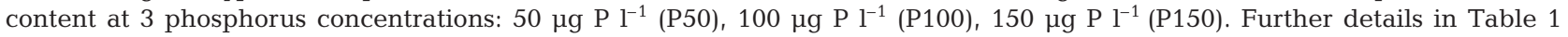

\begin{tabular}{|c|c|c|c|c|c|c|}
\hline Parameter & \multicolumn{2}{|c|}{ P50 } & \multicolumn{2}{|c|}{ P100 } & \multicolumn{2}{|c|}{ P150 } \\
\hline \multicolumn{7}{|l|}{ Cell volume } \\
\hline Bacteria $\left(\mu \mathrm{m}^{3}\right)$ & 0.132 & $(0.088-0.180)$ & 0.131 & $(0.102-0.164)$ & 0.127 & $(0.092-0.159)$ \\
\hline Algae $\left(\mu \mathrm{m}^{3}\right)$ & 418 & $(356-476)$ & 395 & $(286-508)$ & 434 & $(332-522)$ \\
\hline \multicolumn{7}{|l|}{ Cellular carbon } \\
\hline Bacteria (fg $\mathrm{C}$ cell $^{-1}$ ) & 38 & $(27-50)$ & 38 & $(31-46)$ & 37 & $(28-44)$ \\
\hline Algae (fg C cell ${ }^{-1}$ ) & 62386 & $(53715-70652)$ & 57234 & $(40049-75098)$ & 63098 & $(48744-76981)$ \\
\hline \multicolumn{7}{|l|}{ Cellular phosphorus } \\
\hline Bacteria (fg P cell ${ }^{-1}$ ) & 2.4 & $(1.8-3.1)$ & 1.7 & $(1.2-2.5)$ & 1.5 & $(0.9-2.7)$ \\
\hline Algae (fg P cell ${ }^{-1}$ ) & 888 & $(629-1085)$ & 805 & $(703-880)$ & 833 & $(925-1053)$ \\
\hline \multicolumn{7}{|l|}{$\mathrm{C}: \mathrm{P}$ atomic ratio } \\
\hline Bacteria & 44 & $(25-70)$ & 64 & $(47-89)$ & 73 & $(45-99)$ \\
\hline Algae & 193 & $(135-267)$ & 183 & $(131-227)$ & 179 & $(154-201)$ \\
\hline
\end{tabular}

cell volumes decreased. Bacterial growth rate increased especially during the first $2 \mathrm{~d}$; afterwards, algal growth rates were higher (Fig. 4). The bacterial to algal biomass ratios were the lowest of all treatments, with an average value of $0.21(n=7)$. The addition of carbon and phosphorus (+CP) resulted in the highest increase in bacterial growth rate and total bacterial biomass; thus, bacteria attained the same biomass as algae on Days 3 and 4 . Thereafter, the ratio changed again to the benefit of the algae, with a value of 0.16 on Day 6 .

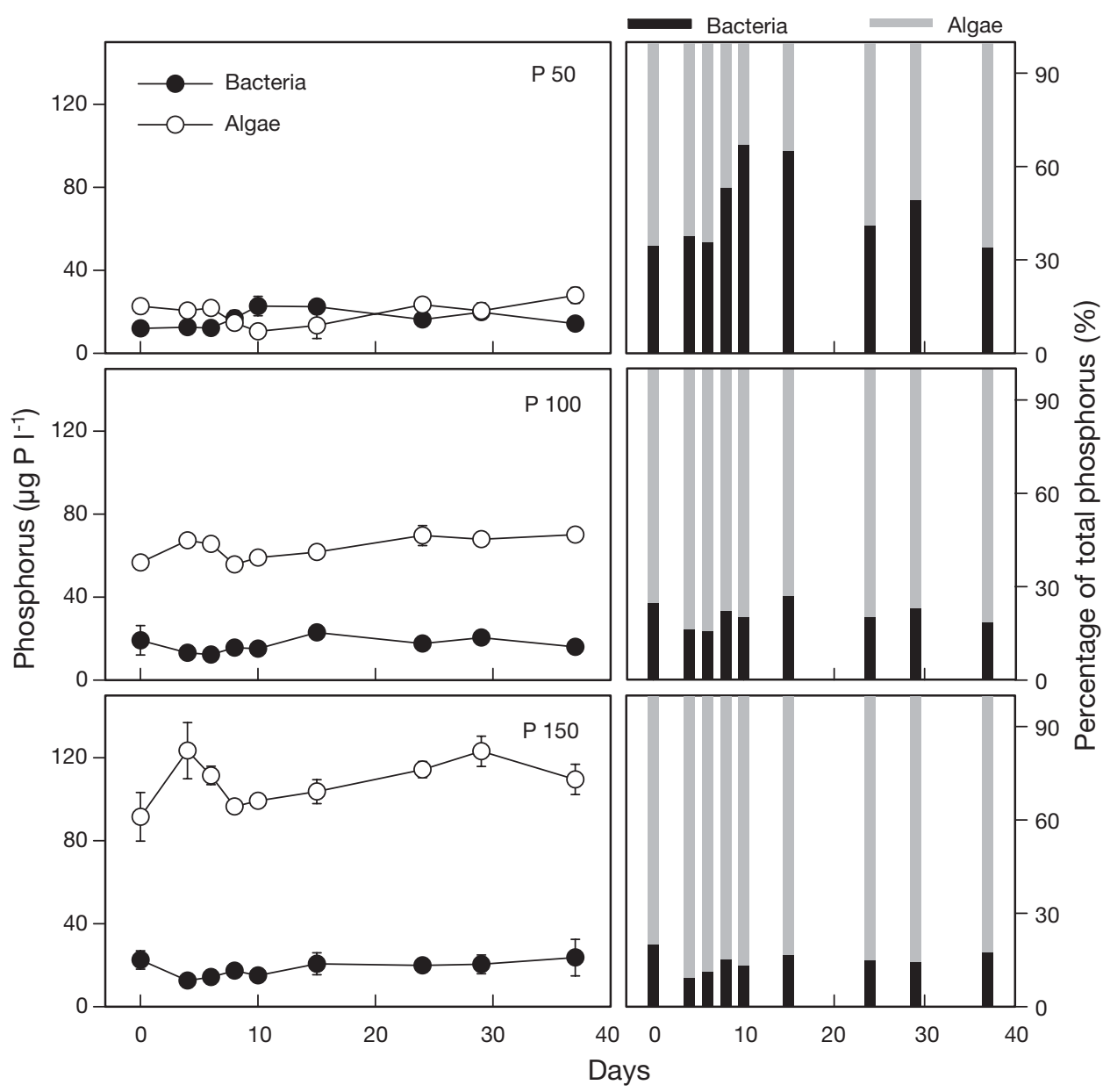

Fig. 3. Algae Cryptomonas phaseolus and mixed bacterial assemblage. Development of total phosphorus over whole investigation period of $37 \mathrm{~d}$ at $3 \mathrm{P}$ concentrations (P50, P100, P150: 50, 100, $150 \mathrm{\mu g} \mathrm{P} \mathrm{l}^{-1}$, respectively) 


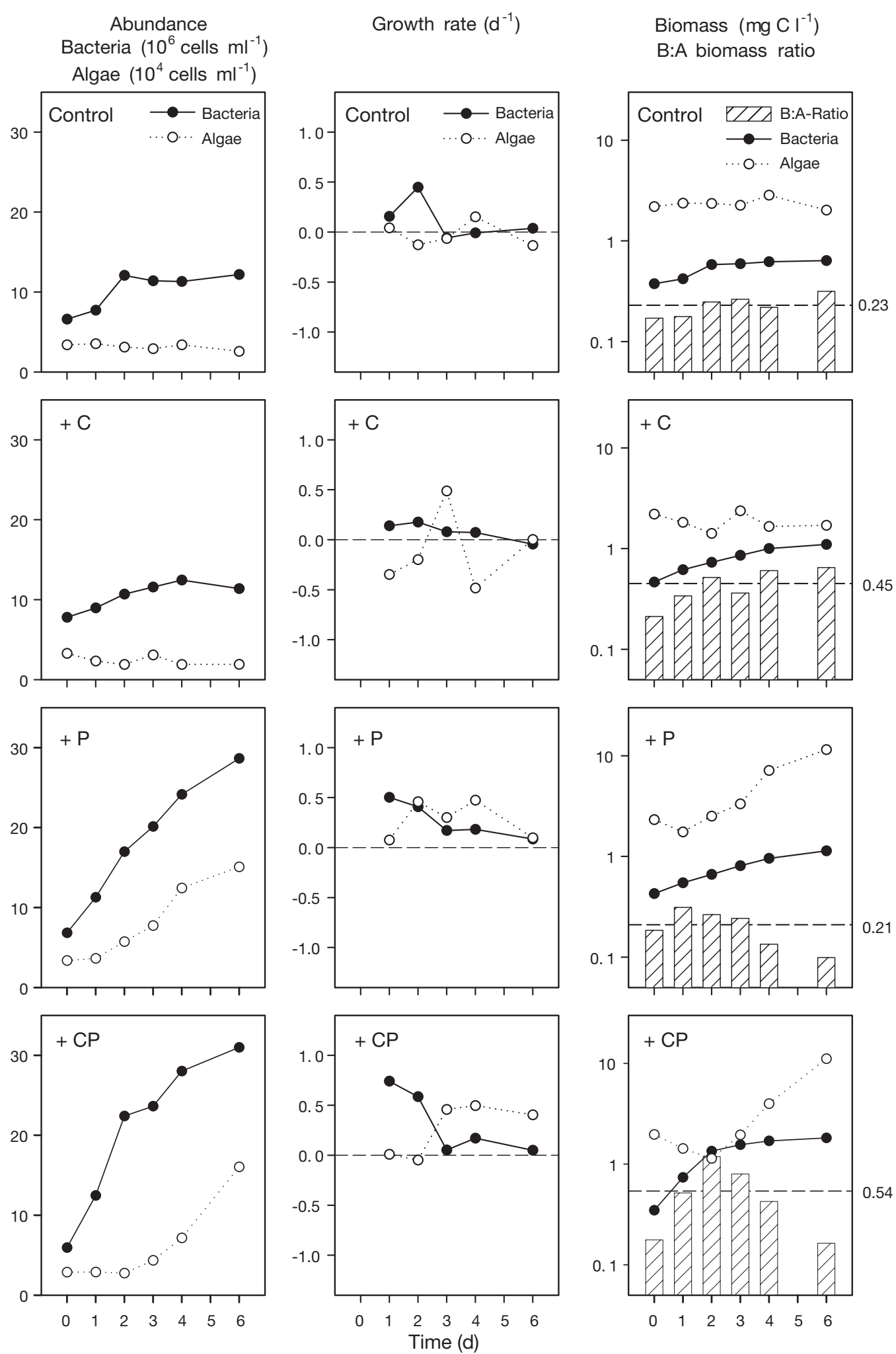

Fig. 4. Algae Cryptomonas phaseolus and mixed bacterial assemblage. Nutrient enrichment of samples originally grown in chemostats at $50 \mu \mathrm{g} \mathrm{P} \mathrm{l}^{-1}$. Samples were kept as batch-cultures for $1 \mathrm{wk}$. Algal and bacterial abundance, growth rate, biomass and biomass ratio are shown for 4 different treatments. Control: no nutrient enrichment; $+\mathrm{C}$ : enriched with glucose (final conc.

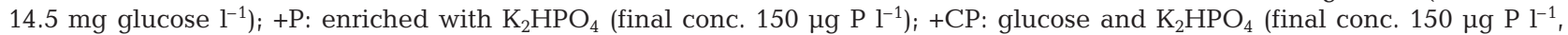
resulting in molar C:P ratio of 100:1). Note logarithmic scale of right-hand graphs 


\section{DISCUSSION}

\section{General remarks on experimental set-up}

In recent years, we have used continuous cultivation for modelling resource-limitation, competition, and predation among planktonic microorganisms (Pernthaler et al. 2001, Posch et al. 2001 and references therein). In several previous studies of algae-bacteria interactions in continuous cultivation, the $\mathrm{P}$ concentrations were defined by varying the dilution rates of the systems (e.g. Currie \& Kalff 1984a, Bratbak \& Thingstad 1985). As growth rates of organisms cultivated in chemostats are regulated by the dilution rate, such an approach causes a decrease in both $L_{p}$ and growth rates. This 'side-effect' on growth rates might substantially influence the interaction between bacteria and algae. For example, lower dilution rates may lead to higher biomass (Makino et al. 2003) and even to higher growth yields of bacteria (Vadstein \& Olsen 1989). Highly increased affinities to $P$ and faster $P$ uptake of bacteria has been observed as a result of decreased dilution rates (Vadstein \& Olsen 1989), suggesting that the 'phytoplankton-bacteria paradox' might be a consequence of growth rates rather than of $\mathrm{P}$ concentrations. Therefore, we chose a different approach by keeping the dilution rate constant. Instead, we varied the P concentrations in the respective cultivation media. Our continuous-flow systems were designed to mimic a gradient of inorganic P supply corresponding to the observed decrease in P load in many temperate lakes after decades of eutrophication in the second half of the 20th century. Although growth rate-related artifacts can be excluded by such an approach, this set-up ignores the possibility that increased P loads might potentially stimulate higher growth rates (Vadstein 2000, Makino et al. 2003).

\section{Phytoplankton-bacteria paradox}

In our experimental communities we confirmed that the phytoplankton-bacteria paradox (sensu Bratbak \& Thingstad 1985) is also valid for constant growth rates, and applicable to interactions of a freshwater microbial community. In addition, we performed a quantitative assessment of this phenomenon with respect to bacterial and algal parameters. Bacterial to algal abundance and biomass ratios closely followed the pattern of $\mathrm{P}$ loads (Fig. 2). At 3-fold higher $L_{P}$, the bacteria to algae ratio was 3 times lower (Table 1). Interestingly, a similar trend has been observed in field studies. The bacteria to algae biomass ratio is usually higher in more oligotrophic waters, and the bacterial biomass increases more slowly than that of the phytoplankton along trophic gradients (Currie 1990, Simon et al. 1992, Gasol \& Duarte 2000, Biddanda et al. 2001). Vrba et al. (2003) suggested a similar pattern, i.e. a decreasing proportion of bacteria in the entire plankton biomass with an increasing trophic status of lakes, where higher trophic levels were absent due to acidification. This might indicate that a basic feature of natural bacterial and algal assemblages such as biomass ratios at different $\mathrm{P}$ concentrations can be modelled adequately in a cultivation system without bacterial and algal predators. In addition, our own observations showed that the phytoplankton-bacteria paradox was still valid for the tested microbial community, even in the presence of hetero- or mixotrophic bacterivores (Posch et al. unpubl.).

In our experiments, the partitioning of $\mathrm{P}$ between bacteria and algae at different $L_{P}$ also reflected the changes in the relative proportions of abundance and biomass. The bacterial to algal $\mathrm{P}$ ratio was 4 -fold higher in P50 than in P150. In other words, in P50, $46 \%$ of the TP consisted of bacterially bound $\mathrm{P}$, whereas in P100 and P150 the percentages of TP bound to bacteria were 21 and $15 \%$, respectively. Similar values were reported by Olsen et al. (2002) for a chemostat experiment with the algae Tetraselmis sp. and a mixed bacterial assemblage. Although bacteria to Tetraselmis biomass ratios were low ( 0.18 to 0.12 with increasing $L_{P}$ ), bacteria bound nearly the same amount of P as algae. Such high percentages are also known from natural systems. Elser et al. (1995) determined the relative contribution of bacterial $\mathrm{P}$ to epilimnetic particulate $\mathrm{P}$, and obtained values of 25 to $34 \%$ for 3 lakes with different trophic status. Jürgens \& Güde (1990) found that on average $\sim 62 \%$ of the particulate $\mathrm{P}$ was incorporated into the bacterial size fraction in Lake Constance (Germany/Switzerland) during summer. In our experiment, the extremely high fraction of $\mathrm{P}$ bound in the bacterial fraction at the lowest $L_{P}$ might, in part, also reflect the lack of P transfer to primary producers by bacterivorous flagellates (Rothhaupt 1997).

\section{Cell characteristics}

Cell morphologies and mean cell volumes of both bacteria and algae varied within a very narrow range, and no relationship between these parameters and P supply could be established. Algal carbon content calculated from cell volumes was in good agreement with the results of direct carbon analyses (Table 3 ). The bacterial volume to carbon conversion factor (LofererKrößbacher et al. 1998) has been verified for both cultures and bacterioplankton from lakes of different trophic status. Therefore, this factor provides a good tool for the estimation of cellular carbon content for a 
Table 3. Cryptomonas phaseolus. Direct measurements of total carbon biomass $\left(\mu \mathrm{g} \mathrm{C}^{-1}\right)$ in cultures enriched with 50 and $150 \mu \mathrm{g}$ $\mathrm{P}^{-1}$. Carbon biomass measured with a carbon analyser (means of triplicate measurements $\pm \mathrm{SD}$ ) and calculated according to volume:carbon conversion factor of Menden-Deuer \& Lessard (2000): $\mathrm{CC}=216 \cdot \mathrm{V}^{0.939}, \mathrm{BM}=\mathrm{CC} \cdot \mathrm{N}$, where CC $=$ cellular carbon

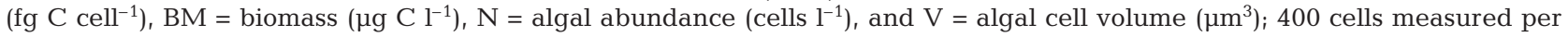
triplicate. All data are from pilot study conducted prior to main experiment

\begin{tabular}{|c|c|c|c|c|c|c|}
\hline \multirow{2}{*}{ Day } & \multirow{2}{*}{$\overline{\mathrm{C} \text { analyzer }}$} & \multirow{2}{*}{$\begin{array}{l}\mathrm{P} 50- \\
\mathrm{C} \text { calculated }\end{array}$} & \multirow[b]{2}{*}{ Percentage } & \multirow[b]{2}{*}{$\mathrm{C}$ analyzer } & \multirow{2}{*}{$\begin{array}{l}\mathrm{P} 150- \\
\mathrm{C} \text { calculated }\end{array}$} & \multirow[b]{2}{*}{ Percentage } \\
\hline & & & & & & \\
\hline 0 & $2718 \pm 414$ & $2682 \pm 519$ & 99 & $8481 \pm 1853$ & $10045 \pm 749$ & 118 \\
\hline 29 & $2148 \pm 103$ & $1943 \pm 21$ & 90 & $9806 \pm 653$ & $9479 \pm 371$ & 97 \\
\hline 40 & $2140 \pm 465$ & $1787 \pm 123$ & 84 & $9319 \pm 559$ & $9888 \pm 304$ & 106 \\
\hline
\end{tabular}

comparison of $\mathrm{C}: \mathrm{P}$ ratios. We found that the carbon content per algal or bacterial cell as inferred from these allometric factors was similar in all treatments (Table 2).

The molar C:P ratio of Cryptomonas phaseolus was ca. 3 times larger than that of bacteria (approx. 185), independent of the amount of P supply. In contrast, the mean $\mathrm{P}$ content of the bacteria significantly varied with decreasing $\mathrm{L}_{\mathrm{P}}$, from 1.4 to $2.5 \mathrm{fg} \mathrm{P}$ cell $^{-1}$, i.e. it was approximately $40 \%$ higher in P50 than in P100 or P150. Little information is available about the changes in the cellular P content of bacteria in the context of P availability (Table 4). Nucleic acids usually represent the largest P pool of microbial cells. Since cellular DNA and ribosome content is typically related to growth rate (Cooper 1991, Kemp et al. 1993), the growth rate affects the cellular $\mathrm{P}$ content. However, in our study, we kept the growth rate constant at $0.41 \mathrm{~d}^{-1}$, and thus, we can exclude the possibility that the observed change in the bacterial cellular $\mathrm{P}$ content was a growth rate-related effect. In some bacteria, $\mathrm{P}$ can also be stored as polyphosphate during growth limitation (Weltin et al. 1996), and microscopic observations of bacterial cells in the P50 treatment did indeed reveal the presence of such polyphosphate granules (data not shown). The bacterial molar C:P ratio fluctuated

Table 4. Summary of published bacterial phosphorus contents and molar C:P ratios. E: estuarine; F: freshwater; M: marine; DAPI: sizing of DAPI-stained bacteria; Size-TEM: sizing of bacteria by transmission electron microscopy; XRMA: X-ray microanalysis. Values are means; in most cases observed ranges are also listed in parentheses

\begin{tabular}{|c|c|c|c|c|c|c|}
\hline $\begin{array}{l}\text { P per cell } \\
\left(\text { fg cell }^{-1}\right)\end{array}$ & $\mathrm{C}: \mathrm{P}$ & $\begin{array}{l}\text { Cell volume } \\
\qquad\left(\mu \mathrm{m}^{3}\right)\end{array}$ & Habitat & Bacteria & Method & Source \\
\hline $\begin{array}{l}0.23 \\
(0.01-7.5)\end{array}$ & $\begin{array}{c}81 \\
(59-143)\end{array}$ & $\begin{array}{c}0.048 \\
(0.002-2)\end{array}$ & M & Native bacteria & Size-TEM, XRMA & Gundersen et al. (2002) \\
\hline $\begin{array}{l}0.8 \\
(0.5-1.4)\end{array}$ & $\begin{array}{c}54 \\
(39-66)\end{array}$ & $\begin{array}{c}0.253 \\
(0.11-0.41)\end{array}$ & $\mathrm{E}, \mathrm{F}, \mathrm{M}$ & Native bacteria, cultures & Size-TEM, XRMA & Fagerbakke et al. (1996) \\
\hline $\begin{array}{l}1.3 \\
3.9\end{array}$ & $\begin{array}{l}56-61 \\
34-41\end{array}$ & $\begin{array}{l}0.11-0.12 \\
0.17-0.23\end{array}$ & $\mathrm{~F}$ & Cultures, C-limitation & Molybdate method & Jürgens \& Güde (1990) \\
\hline $\begin{array}{l}3.0 \\
3.5\end{array}$ & $\begin{array}{c}81-96 \\
80\end{array}$ & $\begin{array}{l}0.21-0.26 \\
0.20-0.23\end{array}$ & $\mathrm{~F}$ & Cultures, P-limitation & Molybdate method & Jürgens \& Güde (1990) \\
\hline $\begin{array}{l}1.5 \\
(0.7-2.6)\end{array}$ & $\begin{array}{c}48 \\
(39-70)\end{array}$ & $\begin{array}{c}0.35 \\
(0.15-0.60)\end{array}$ & M & $\begin{array}{l}\text { Native bacteria, enriched } \\
\text { with amino acids and P }\end{array}$ & Size-TEM, XRMA & Tuomi et al. (1995) \\
\hline $\begin{array}{l}1.5 \\
(0.9-2.7)\end{array}$ & $\begin{array}{c}73 \\
(45-99)\end{array}$ & $\begin{array}{c}0.127 \\
(0.09-0.16)\end{array}$ & $\mathrm{F}$ & $\begin{array}{l}\text { Culture together } \\
\text { with algae, high } \mathrm{P}\end{array}$ & $\begin{array}{l}\text { DAPI, } \\
\text { molybdate method }\end{array}$ & This study \\
\hline $\begin{array}{l}1.7 \\
(1.2-2.5)\end{array}$ & $\begin{array}{c}64 \\
(47-89)\end{array}$ & $\begin{array}{c}0.131 \\
(0.10-0.16)\end{array}$ & $\mathrm{F}$ & Medium P & $\begin{array}{l}\text { DAPI, } \\
\text { molybdate method }\end{array}$ & This study \\
\hline $\begin{array}{l}2.4 \\
(1.8-3.1)\end{array}$ & $\begin{array}{c}44 \\
(25-70)\end{array}$ & $\begin{array}{c}0.132 \\
(0.09-0.18)\end{array}$ & $\mathrm{F}$ & Low $\mathrm{P}$ & $\begin{array}{l}\text { DAPI, } \\
\text { molybdate method }\end{array}$ & This study \\
\hline $\begin{array}{l}2.3 \\
(2.2-2.3)\end{array}$ & $\begin{array}{c}178 \\
(176-180)\end{array}$ & $\begin{array}{c}2.38 \\
(1.70-3.31)\end{array}$ & M & Isolates, P-limitation & Size-TEM, XRMA & Vrede et al. (2002) \\
\hline $\begin{array}{l}2.8 \\
(1.4-4.4)\end{array}$ & $\begin{array}{c}42 \\
(25-70)\end{array}$ & $\begin{array}{c}0.45 \\
(0.28-0.91)\end{array}$ & M & Isolates, C-limitation & Size-TEM, XRMA & Vrede et al. (2002) \\
\hline $\begin{array}{l}5.7 \\
(4.7-8.3)\end{array}$ & $\begin{array}{c}49 \\
(29-56)\end{array}$ & $\begin{array}{c}1.40 \\
(0.85-1.99)\end{array}$ & M & Isolates, N-limitation & Size-TEM, XRMA & Vrede et al. (2002) \\
\hline $\begin{array}{l}12 \\
(8.5-16)\end{array}$ & $\begin{array}{c}35 \\
(26-50)\end{array}$ & $\begin{array}{c}1.78 \\
(0.81-3.00)\end{array}$ & M & $\begin{array}{l}\text { Isolates, } \\
\text { Exponential growth }\end{array}$ & Size-TEM, XRMA & Vrede et al. (2002) \\
\hline
\end{tabular}


between 25 and 100 between treatments and increased with increasing $L_{P}$ (Table 2). Bacterial cells grown under $\mathrm{P}$ limitation typically have $\mathrm{C}: \mathrm{P}$ ratios in the range of 100:1 and higher (Jürgens \& Güde 1990, Vrede et al. 2002, Makino et al. 2003). The C:P ratio for cells grown under $\mathrm{C}$ or mineral limitation other than $\mathrm{P}$ falls below 50:1 (Jürgens \& Güde 1990, Vrede et al. 2002). The observed bacterial C:P ratios thus provided indirect evidence that bacteria in all treatments were C-limited. Therefore, we performed enrichment experiments to test this hypothesis (Fig. 4).

\section{Mechanistic explanation of phytoplankton-bacteria paradox}

Our enrichment experiments (Fig. 4) provide a first insight into why the interactions between bacteria and algae change with increasing $L_{P}$. The exclusive addition of $\mathrm{C}$ to the microbial assemblages from the P50 treatments primarily resulted in an increase in bacterial cell volume and total biomass. In contrast, enrichment with $\mathrm{P}$ led to a steep increase in the bacterial growth rate at the beginning of the experiment, followed by increased growth dynamics of the algae. This is in agreement with previous observations, and it probably reflects the different uptake kinetics of these organisms (Rothhaupt \& Güde 1992). Bacteria usually show higher specific uptake rates and affinities to $\mathrm{P}$ than algae, and therefore are frequently superior competitors of algae at lower $\mathrm{P}$ concentrations in aquatic systems (Rhee 1972, Currie \& Kalff 1984a, Bratbak \& Thingstad 1985, Gurung et al. 1999). In contrast, the competition for P can shift towards the benefit of algae at increased amounts of available P (Rothhaupt \& Güde 1992). In our enrichment study, algal biomass increased much faster than bacterial biomass after the addition of surplus $P$.

However, bacteria from the P50 treatments seemed to be simultaneously co-limited by both $\mathrm{C}$ and $\mathrm{P}$, as the addition of both elements resulted in significantly higher initial growth rates and higher total biomass (Fig. 4). Moreover, the bacterial to algal biomass ratio more than doubled compared to the addition of P only (0.54 and 0.21, respectively, Fig. 4). This suggests that the bacteria in our systems profited from their higher $\mathrm{P}$ uptake capacities at lower $\mathrm{L}_{\mathrm{P}}$, but that bacteria were also C-limited in all 3 treatments (P50, P100, P150).

\section{Variability in bacteria-algae relationships}

The observed simultaneous $\mathrm{C}$ and $\mathrm{P}$ limitation of the bacterial assemblage raises the interesting question as to whether such a double feedback between bacterial and algal growth could result in increased instability of the community as a whole. Already, in a pilot study of

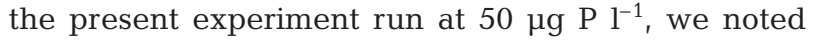
that the high ratio of bacterial to algal biomass (and $\mathrm{P}$ ) did not seem to be stable during longer periods (Table 1, Figs. $2 \& 3$ ). We found that the ratio of bacteria to algae strongly shifted to the benefit of bacteria for certain periods (days to weeks). During these phases of imbalance, the bacteria incorporated up to $80 \%$ of available $\mathrm{P}$ and algal abundance and biomass decreased rapidly. These imbalance situations can partly be compensated by grazing activities of bacterivorous protists, thus decreasing the strength of bacteria as competitors for algae (Salcher et al. 2005, this issue). However, the mixed bacterial community could not displace or outcompete the algae, as Cryptomonas phaseolus was still the only available carbon source for the bacteria. As a consequence, the ratios changed again to the benefit of algae, but showed more instability, i.e. periodical oscillations in the bacteria-algae ratio (Salcher et al. 2005). To our knowledge, such an imbalance situation has not been described previously, and we intend to follow-up these observations in future studies on bacteria-algae interactions. Continuous cultivation studies might provide an adaequate tool for exploring the long-term stability of bacteria-algae relationships at different $\mathrm{P}$ loads.

Acknowledgements. This study was supported by the Austrian Science Fund (FWF P14637-BIO) and by the Max Planck Society. We thank Josef Franzoi for his efforts in phosphorus analysis, Ruben Sommaruga for commenting on the manuscript, and Liliana Krotz (ThermoFinnigan, Italy) for measuring the algal carbon content.

\section{LITERATURE CITED}

Bertoni R (1978) Automatic determination of carbon and nitrogen in suspended matter of natural water with Carlo Erba 1106 Element Analyzer. Mem Ist Ital Idrobiol 36: 297-301

Biddanda B, Ogdahl M, Cotner J (2001) Dominance of bacterial metabolism in oligotrophic relative to eutrophic waters. Limnol Oceanogr 46:730-739

Bratbak G, Thingstad TF (1985) Phytoplankton-bacteria interaction: an apparent paradox? Analysis of a model system with both competition and commensalism. Mar Ecol Prog Ser 25:23-30

Chrzanowski TH, Kyle M, Elser JJ, Sterner RW (1996) Element ratios and growth dynamics of bacteria in an oligotrophic Canadian shield lake. Aquat Microb Ecol 11: 119-125

Cooper S (1991) Bacterial growth and division. Academic Press, London

Currie DJ (1990) Large-scale variability and interactions among phytoplankton, bacterioplankton, and phosphorus. Limnol Oceanogr 35:1437-1455

Currie DJ, Kalff J (1984a) A comparison of the abilities of freshwater algae and bacteria to acquire and retain 
phosphorus. Limnol Oceanogr 29:298-310

Currie DJ, Kalff J (1984b) Can bacteria outcompete phytoplankton for phosphorus. A chemostat test. Microb Ecol 10:205-216

Elser JJ, Chrzanowski TH, Sterner RW, Schampel JH, Foster DK (1995) Elemental ratios and the uptake and release of nutrients by phytoplankton and bacteria in 3 lakes of the Canadian Shield. Microb Ecol 29:145-162

Fagerbakke KM, Heldal M, Norland S (1996) Content of carbon, nitrogen, oxygen, sulphur and phosphorus in native aquatic and cultured bacteria. Aquat Microb Ecol 10:15-27

Fogg GE (1971) Extracellular products of algae in freshwater. Ergeb Limnol 5:1-25

Gächter R, Bloesch J (1985) Seasonal and vertical variation in the $\mathrm{C}: \mathrm{P}$ ratio of suspended and settling seston of lakes. Hydrobiologia 128:193-200

Gasol JM, Duarte CM (2000) Comparative analyses in aquatic microbial ecology: How far do they go? FEMS Microbiol Ecol 31:99-106

Grossart HP (1999) Interactions between marine bacteria and axenic diatoms (Cylindrotheca fusiformis, Nitzschia laevis, and Thalassiosira weissflogii) incubated under various conditions in the lab. Aquat Microb Ecol 19:1-11

Guillard RRL, Lorenzen CJ (1972) Yellow-green algae with chlorophyllidae $c$. J Phycol 8:10-14

Gundersen K, Heldal M, Norland S, Purdie DA, Knap AH (2002) Elemental C, N, and P cell content of individual bacteria collected at the Bermuda Atlantic time-series study (BATS) site. Limnol Oceanogr 47:1525-1530

Gurung TB, Urabe J, Nakanishi M (1999) Regulation of the relationship between phytoplankton Scenedesmus acutus and heterotrophic bacteria by the balance of light and nutrients. Aquat Microb Ecol 17:27-35

Jürgens K, Güde H (1990) Incorporation and release of phosphorus by planktonic bacteria and phagotrophic flagellates. Mar Ecol Prog Ser 59:271-284

Kemp PF, Lee S, LaRoche J (1993) Estimating the growth rate of slowly growing marine bacteria from RNA content. Appl Environ Microbiol 59:2594-2601

Loferer-Krößbacher M, Klima J, Psenner R (1998) Determination of bacterial cell dry mass by transmission electron microscopy and densitometric image analyses. Appl Environ Microbiol 64:688-694

Makino W, Cotner JB, Sterner RW, Elser JJ (2003) Are bacteria more like plants or animals? Growth rate and resource dependence of bacterial C:N:P stoichiometry. Funct Ecol 17:121-130

Menden-Deuer S, Lessard EJ (2000) Carbon to volume relationship for dinoflagellates, diatoms, and other protist plankton. Limnol Oceanogr 45:569-579

Olsen Y, Reinertsen H, Vadstein O (2002) Can phosphorus limitation inhibit dissolved organic carbon consumption in aquatic microbial food webs? A study of 3 food web structures in microcosms. Microb Ecol 43:353-366

Pernthaler J, Posch T, Šimek K, Vrba J and 5 others (2001) Predator-specific enrichment of Actinobacteria from a cosmopolitan freshwater clade in mixed continuous culture. Appl Environ Microbiol 67:2145-2155

Porter KG, Feig YS (1980) The use of DAPI for identifying and counting aquatic microflora. Limnol Oceanogr 25:943-948

Posch T, Šimek K, Vrba J, Pernthaler J, Nedoma J, Sattler B,

Editorial responsibility: David Caron,

Los Angeles, California, USA
Sonntag B, Psenner R (1999) Predator-induced changes of bacterial size-structure and productivity studied on an experimental microbial community. Aquat Microb Ecol 18:235-246

Posch T, Jezbera J, Vrba J, Šimek K, Pernthaler J, Andreatta S, Sonntag B (2001) Size selective feeding in Cyclidium glaucoma (Ciliophora, Scuticociliatida) and its effects on bacterial community structure: a study from a continuous cultivation system. Microb Ecol 42:217-227

Rhee GY (1972) Competition between an alga and an aquatic bacterium for phosphate. Limnol Oceanogr 17:505-514

Rothhaupt KO (1997) Nutrient turnover by freshwater bacterivorous flagellates: differences between a heterotrophic and a mixotrophic chrysophyte. Aquat Microb Ecol 12:65-70

Rothhaupt KO, Güde H (1992) The influence of spatial and temporal concentration gradients on phosphate partitioning between different size fractions of plankton: further evidence and possible causes. Limnol Oceanogr 37 : 739-749

Salcher MM, Pernthaler J, Psenner R, Posch T (2005) Succession of bacterial grazing defense mechanisms against protistan predators in an experimental microbial community. Aquat Microb Ecol 38:215-229

Schmid M, Ambühl H (1965) Die Bestimmung geringster Mengen Gesamtphosphor in Wasser und Biomasse. Schweiz Z Hydrol 27:184-192

Šimek K, Vrba J, Pernthaler J, Posch T, Hartman P, Nedoma J, Psenner R (1997) Morphological and genotypic shifts in an experimental bacterial community influenced by protists of contrasting feeding modes. Appl Environ Microbiol 63: 587-595

Simon M, Cho BC, Azam F (1992) Significance of bacterial biomass in lakes and the ocean: comparison to phytoplankton biomass and biogeochemical implications. Mar Ecol Prog Ser 86:103-110

Tuomi P, Fagerbakke KM, Bratbak G, Heldal M (1995) Nutritional enrichment of a microbial community: the effects on activity, elemental composition, community structure and virus production. FEMS Microbiol Ecol 16:123-134

Vadstein O (2000) Heterotrophic, planktonic bacteria and cycling of phosphorus. Phosphorus requirements, competitive ability, and food web interactions. Adv Microb Ecol 16:115-167

Vadstein O, Olsen Y (1989) Chemical composition and phosphate uptake kinetics of limnetic bacterial communities cultured in chemostats under phosphorus limitation. Limnol Oceanogr 34:939-946

Vrba J, Nedoma J, Kohout L, Kopáček J, Nedbalová L, Ráčková P, Šimek K (2003) Massive occurrence of heterotrophic filaments in acidified lakes: seasonal dynamics and composition. FEMS Microbiol Ecol 46:281-294

Vrede K, Heldal M, Norland S, Bratbak G (2002) Elemental composition $(\mathrm{C}, \mathrm{N}, \mathrm{P})$ and cell volume of exponentially growing and nutrient-limited bacterioplankton. Appl Environ Microbiol 68:2965-2971

Weltin D, Hoffmeister D, Dott W, Kämpfer P (1996) Studies on polyphosphate and poly- $\beta$-hydroxylkanoate accumulation in Acinetobacter johnsonii 120 and some other bacteria from activated sludge in batch and continuous culture. Acta Biotechnol 16:91-102

Submitted: August 17, 2004; Accepted: December 16, 2004 Proofs received from author(s): March 2, 2005 